Article

\title{
Nanoindentation of Chromium Oxide Possessing Superior Hardness among Atomic-Layer-Deposited Oxides
}

\author{
Taivo Jõgiaas*(D), Aivar Tarre ${ }^{(D)}$, Hugo Mändar, Jekaterina Kozlova and Aile Tamm (D)
}

check for updates

Citation: Jõgiaas, T.; Tarre, A.; Mändar, H.; Kozlova, J.; Tamm, A Nanoindentation of Chromium Oxide Possessing Superior Hardness among Atomic-Layer-Deposited Oxides. Nanomaterials 2022, 12, 82. https://doi.org/10.3390/nano12010082 Academic Editor: Yang-Tse Cheng

Received: 24 November 2021 Accepted: 24 December 2021 Published: 29 December 2021

Publisher's Note: MDPI stays neutral with regard to jurisdictional claims in published maps and institutional affiliations.

Copyright: (C) 2021 by the authors. Licensee MDPI, Basel, Switzerland. This article is an open access article distributed under the terms and conditions of the Creative Commons Attribution (CC BY) license (https:// creativecommons.org/licenses/by/ $4.0 /)$.
Department of Materials Science, Institute of Physics, University of Tartu, W. Ostwald Str. 1, 50411 Tartu, Estonia; aivar.tarre@ut.ee (A.T.); hugo.mandar@ut.ee (H.M.); jekaterina.kozlova@ut.ee (J.K.); aile.tamm@ut.ee (A.T.)

* Correspondence: taivo.jogiaas@ut.ee

\begin{abstract}
Chromium (III) oxide is a technologically interesting material with attractive chemical, catalytic, magnetic and mechanical properties. It can be produced by different chemical and physical methods, for instance, by metal-organic chemical vapor deposition, thermal decomposition of chromium nitrate $\mathrm{Cr}\left(\mathrm{NO}_{3}\right)_{3}$ or ammonium dichromate $\left(\mathrm{NH}_{4}\right)_{2} \mathrm{Cr}_{2} \mathrm{O}_{7}$, magnetron sputtering and atomic layer deposition. The latter method was used in the current work to deposit $\mathrm{Cr}_{2} \mathrm{O}_{3}$ thin films with thicknesses from 28 to $400 \mathrm{~nm}$ at deposition temperatures from 330 to $465{ }^{\circ} \mathrm{C}$. The phase composition, crystallite size, hardness and modulus of elasticity were measured. The deposited $\mathrm{Cr}_{2} \mathrm{O}_{3}$ thin films had different structures from X-ray amorphous to crystalline $\alpha-\mathrm{Cr}_{2} \mathrm{O}_{3}$ (eskolaite) structures. The averaged hardness of the films on $\mathrm{SiO}_{2}$ glass substrate varied from 12 to $22 \mathrm{GPa}$ and the moduli were in the range of 76-180 GPa, as determined by nanoindentation. Lower values included some influence from a softer deposition substrate. The results indicate that $\mathrm{Cr}_{2} \mathrm{O}_{3}$ could be a promising material as a mechanically protective thin film applicable, for instance, in microelectromechanical devices.
\end{abstract}

Keywords: nanoindentation; chromium (III) oxide; atomic layer deposition; hardness; elastic modulus

\section{Introduction}

Chromium (III) oxide has been researched as a corrosion- and wear-resistant, mechanically protective hard coating, a component in glasses and glass ceramics, a cermet-type hard material or in other composites or as a sintering additive [1-12]. Some research has been focused on doped and pristine $\mathrm{Cr}_{2} \mathrm{O}_{3}$ 's optical, magnetic, catalytic or sensory properties [13-23].

A number of different physical and chemical methods have been employed to produce $\mathrm{Cr}_{2} \mathrm{O}_{3}$ or the materials containing it. The physical techniques have included detonation and plasma spraying, different magnetron sputtering techniques and pulsed laser deposition [1,2,10-12,15,24]. The chemical techniques have included thermal decomposition of or co-precipitation from $\mathrm{Cr}\left(\mathrm{NO}_{3}\right)_{3} \cdot 9 \mathrm{H}_{2} \mathrm{O}$, chemical vapor deposition (CVD) from $\mathrm{CrCl}_{3}$ and $\mathrm{H}_{2} \mathrm{O}$ at $900{ }^{\circ} \mathrm{C}$ or $\mathrm{CrO}_{3}$ and $\mathrm{I}_{2}$ at $500{ }^{\circ} \mathrm{C}$, metal-organic chemical vapor deposition from $\mathrm{Cr}(\mathrm{CO})_{6}$, laser-assisted $\mathrm{CVD}$ from $\mathrm{O}_{2}$ and $\mathrm{Cr}(\mathrm{CO})_{6}$ and atomic layer deposition (ALD) from $\mathrm{CrO}_{2} \mathrm{Cl}_{2}$ and $\mathrm{CH}_{3} \mathrm{OH}$ precursors or from chromium acetyl acetonate and ozone [9,13,14,25-29].

Aside from the usual thin film deposition, some of the used techniques have resulted in various appearances of $\mathrm{Cr}_{2} \mathrm{O}_{3}$. For instance, the $\mathrm{CVD}$ from $\mathrm{CrCl}_{3}$ and $\mathrm{H}_{2} \mathrm{O}$ at $900{ }^{\circ} \mathrm{C}$ resulted in single crystalline $\mathrm{Cr}_{2} \mathrm{O}_{3}$ nanowires and nanobelts [14]. The decomposition of $\mathrm{Cr}\left(\mathrm{NO}_{3}\right)_{3} \cdot 9 \mathrm{H}_{2} \mathrm{O}$, mixed with zirconia-toughened alumina at $600{ }^{\circ} \mathrm{C}$, gave microparticles, whereas the co-precipitation from the same precursor resulted in nanoparticles $[9,13]$. CVD using $\mathrm{CrO}_{3}$ and $\mathrm{I}_{2}$ at $500{ }^{\circ} \mathrm{C}$ as precursors resulted in $\mathrm{Cr}_{2} \mathrm{O}_{3}$ flakes [21].

The previous reports have indicated the $\mathrm{Cr}_{2} \mathrm{O}_{3}$ thin films possess a high hardness of over $20 \mathrm{GPa}[10,14,15,30-32]$. In some conditions the processes produced chromia with lower hardness, even down to an 8-10 GPa level [14]. Reported values for the moduli 
range from 160 to about $290 \mathrm{GPa}$. The lower hardness and modulus values tend to appear in the amorphous chromia, but the crystalline counterparts have higher values $[10,14,15]$. It has been shown that $\mathrm{Cr}_{2} \mathrm{O}_{3}$, alloyed with other elements, could result in a super-hard material [10].

Compared to previously noted techniques, ALD allows to deposit conformal thin films on basically arbitrary three-dimensional shapes through the employment of the self-limiting irreversible and saturated surface reactions [33]. This feature makes ALD a very good tool to coat parts of micro-electromechanical devices or other systems to create surfaces with modified mechanical properties or, for instance, to act as a catalyst on a mesoporous substrate [34-38].

Even though $\mathrm{Cr}_{2} \mathrm{O}_{3}$ has been deposited before using ALD, the mechanical properties have not been reported [21,22]. The present work was dedicated to the investigation of the viability of atomic-layer-deposited $\mathrm{Cr}_{2} \mathrm{O}_{3}$ as a potentially hard and stiff material to be used as a mechanically protective or modifying thin film coating in micro- or nanoelectromechanical devices [31]. The crystallinity, the effect of the growth temperature and the thickness of the thin films were correlated to the nanoindentation hardness and modulus.

\section{Experimental}

The $\mathrm{Cr}_{2} \mathrm{O}_{3}$ thin films were deposited from $\mathrm{CrO}_{2} \mathrm{Cl}_{2}$ and $\mathrm{CH}_{3} \mathrm{OH}$ (Sigma-Aldrich, Darmstadt, Germany) in an in-house built atomic layer deposition reactor [39]. The detailed description and results can be found in previously published article [26]. Briefly, the films were grown on fused silica substrates at the growth temperature $T_{g}$ of 330, 375, 420 and $465{ }^{\circ} \mathrm{C}$. The cycle count was varied between $400-4300$ ALD cycles. Each cycle consisted of $0.2 \mathrm{~s}$ exposure to $\mathrm{CrO}_{2} \mathrm{Cl}_{2}, 2 \mathrm{~s}$ purge with dry $\mathrm{N}_{2}, 2 \mathrm{~s}$ exposure to $\mathrm{CH}_{3} \mathrm{OH}$ vapors and another $2 \mathrm{~s} \mathrm{~N}_{2}$ purge. Both precursors were volatilized at $-20{ }^{\circ} \mathrm{C}$.

The crystallographic phase composition and the apparent crystallite size $\mathrm{D}_{\mathrm{v}}$ were determined in direction of the normal to the lattice plane (104) by using Voigt decomposition analysis and SRM-660 (NIST, Gaithersburg, MD, USA) as reference material for diffraction peak instrumental broadening calibration [40]. Thickness of the films was determined using X-ray diffraction (XRD) and reflectivity (XRR) methods on diffractometer SmartLab ${ }^{\mathrm{TM}}$ (Rigaku, Tokyo, Japan) working at $8.1 \mathrm{~kW}(\mathrm{Cu} \mathrm{K} \alpha$ radiation, $\lambda=0.154178 \mathrm{~nm})$. Asymmetric $2 \theta$-scan at fixed grazing incidence angle of $\omega=0.42^{\circ}$ (GIXRD) was used for phase composition analysis. In the GIXRD experiment, the $\mathrm{D}_{\mathrm{v}}$ was determined in direction that is approximately $16.6^{\circ}$ inclined to the sample surface normal. Texture coefficient of reflections $\left(\mathrm{T}_{h k l}\right)$ was calculated from the following equation [41]: $\mathrm{T}_{\mathrm{hkl}}=\mathrm{I}^{\mathrm{OBS}}{ }_{\mathrm{hkl}} / \mathrm{I}^{\mathrm{DB}}{ }_{\mathrm{hkl}} /\left\langle\mathrm{I}^{\mathrm{OBS}}\right\rangle$, where $\mathrm{I}^{\mathrm{OBS}}{ }_{h k l}$ is the observed absolute intensity of the reflection hkl; $\mathrm{I}^{\mathrm{DB}}{ }_{\mathrm{hkl}}$ is the relative intensity of reference reflection hkl in the database; and $\left\langle\mathrm{I}^{\mathrm{OBS}}>\right.$ is an average over all observed reflections of the ratio of observed to reference peak intensity values. $\mathrm{T}_{\mathrm{hkl}}$ is close to 1.0 for a randomly oriented polycrystalline sample and approaches to the number of observed reflections for a sample showing high preferred (hkl) orientation.

High-resolution scanning transmission electron microscopy (STEM) investigations were carried out by using a Titan Themis 200 microscope (FEI, Hillsboro, OR, USA) equipped with a Cs-probe corrector and operated at $200 \mathrm{kV}$. A sample for the STEM study in the form of thin cross-sectional lamella was prepared by a focused ion beam by using an in-situ lift-off technique in the scanning electron microscope Helios NanoLab 600 Dual Beam system (FEI, Hillsboro, OR, USA). Prior to the lamella preparation procedure, a platinum layer was deposited on the specimen by magnetron sputtering to minimize the charging of the specimen and to protect the chromium oxide film from the ion beam milling effect.

The hardness and elastic modulus of $\mathrm{ALD} \mathrm{Cr}_{2} \mathrm{O}_{3}$ films were investigated by using nanoindentation device Bruker Hysitron Triboindenter TI 980 (Billerica, MA, USA; Minneapolis, MN, USA). The samples were measured in continuous stiffness mode by using a Berkovich-type diamond tip. The device was calibrated by using a fused quartz standard (Bruker) with defined hardness of $9.25 \mathrm{GPa}$ and reduced modulus of 69.6 GPa. The overall 
arithmetic average of 17 measurements of the fused quartz was $9.18 \mathrm{GPa}$ for hardness and $70.1 \mathrm{GPa}$ for modulus. The strain rate of $0.05 \mathrm{~nm} / \mathrm{s}$ and tip vibration frequency $(220 \mathrm{~Hz})$ were kept constant during the calibration and measurements. The calibrations were performed before and after measurements. The latter results indicated that the tip was still in good condition and assured the correctness of the measurements. The calibrations indicated that the valid displacement range was approximately from $20 \mathrm{~nm}$ to $100 \mathrm{~nm}$. In the given range, the deposition substrate $\left(\mathrm{SiO}_{2}\right.$ glass) had hardness of $8 \pm 0.5 \mathrm{GPa}$ and modulus of $61 \pm 1.5 \mathrm{GPa}$ (here, the error margins indicate the absolute minimum and maximum deviation at a given measurement point). The standard deviations of a single measurement remained near $3 \mathrm{GPa}$ for modulus and $0.3 \mathrm{GPa}$ for hardness at displacements around $20 \mathrm{~nm}$. The deviations somewhat reduced towards higher displacements. Any single indentation measurement consisted of 61 data points in total, spread along the displacement range. The data points below displacements of $15 \mathrm{~nm}$ were removed. The data points near $20 \mathrm{~nm}$ of displacement were considered through analysis.

Due to the fact that some of the thin films were very thin in this study, the fused $\mathrm{SiO}_{2}$ glass made a good deposition substrate as it was free of any pile-up, sink-in or cracking effects which might occur during nanoindentation, possibly discrediting data analysis. Additionally, this is the reason for $\mathrm{SiO}_{2}$ glass usage as a calibration standard. As a glassy material, the substrate should have isotropic mechanical properties, which should avoid problems, such as film-induced cracking of a substrate [42].

Thirty separate continuous stiffness measurements were performed on each sample. Some low-quality measurements were removed, for instance, because of unsuitably high or unstable (thermal or positioning) drift rate of $0.29 \mathrm{~nm} / \mathrm{s}$, reducing the count of acceptable measurements by 5 in the worst case. Maximum drift level of $0.05 \mathrm{~nm} / \mathrm{s}$ was the default acceptance level.

\section{Results and Discussion}

\subsection{X-ray Diffraction}

The crystallinity affects the (mechanical) properties of a material. Therefore, it is essential to measure the deposited thin film crystallographic properties, such as crystallinity and crystallite size.

Figure 1 shows that the crystallinity increased with the increase of the growth temperature $\mathrm{T}_{\mathrm{g}}$. The sample deposited at $330{ }^{\circ} \mathrm{C}$ was $\mathrm{X}$-ray amorphous, but the samples deposited at higher temperatures showed reflections that were identified as belonging to $\alpha-\mathrm{Cr}_{2} \mathrm{O}_{3}$ (mineral eskolaite, ICDD PDF-2 file number 01-078-5435).

The diffractograms of thin films with different cycle counts are shown in Figure 2.

Figure $2 b$ shows the variation of texture coefficient $T_{h k l}$ for the dominating reflections (104), (006), (116) and (1010) as a function of the film thickness. The value of $\mathrm{T}_{\mathrm{hkl}}$ for the reflection 006 was a few times higher compared to the values for the other reflections. Pang et al. showed that the mechanical properties of $\mathrm{Cr}_{2} \mathrm{O}_{3}$ films change with the texture [30]. For instance, a film with strong (300) texture had hardness of about $28 \mathrm{GPa}$ but was reduced to $20 \mathrm{GPa}$ for a low-textured film. Similar results were gained by Luo et al. [15].

Considering that, in the GIXRD analysis, these observed reflections were generated from lattice planes that were inclined to the sample surface in the angle range of $20-38^{\circ}$ and, by assuming modest mosaicity of the film, it can be concluded that the preferred growth direction of the films was close to the crystallographic [001] direction. The mosaicity of the films was determined and the preferred growth plane characterized in more detail also by symmetrical $\theta / 2 \theta$ and in-plane XRD analysis for the two thickest samples (230 and $400 \mathrm{~nm}$ ) that allowed to record diffraction reflections with acceptable signal-to-noise ratio for both of the analysis modes. 


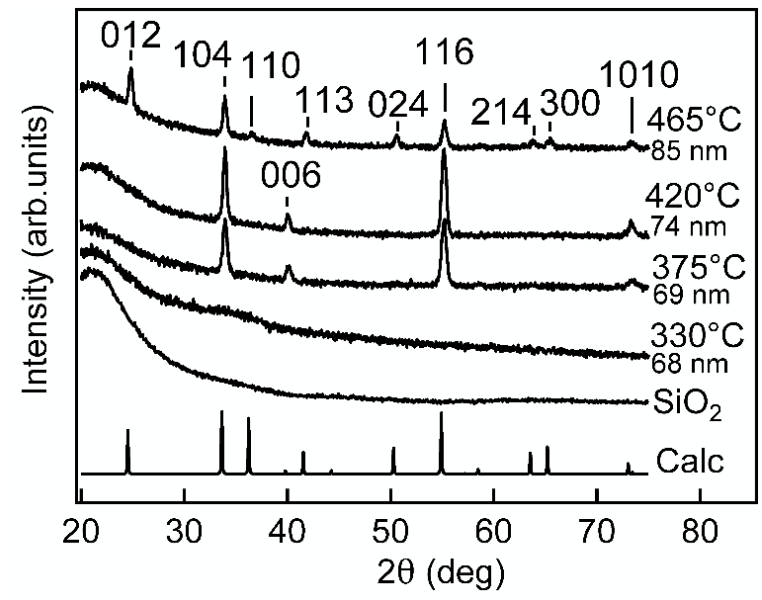

Figure 1. Diffraction patterns of $\mathrm{ALD} \mathrm{Cr}_{2} \mathrm{O}_{3}$ films grown at different temperatures. The thin film thicknesses were $68-85 \mathrm{~nm}$. The diffraction pattern denoted as Calc was calculated from crystal structure data of eskolaite corresponding to the inorganic crystal structure database collection code 261801. The labels at the reflections are the Miller indices of corresponding lattice planes.
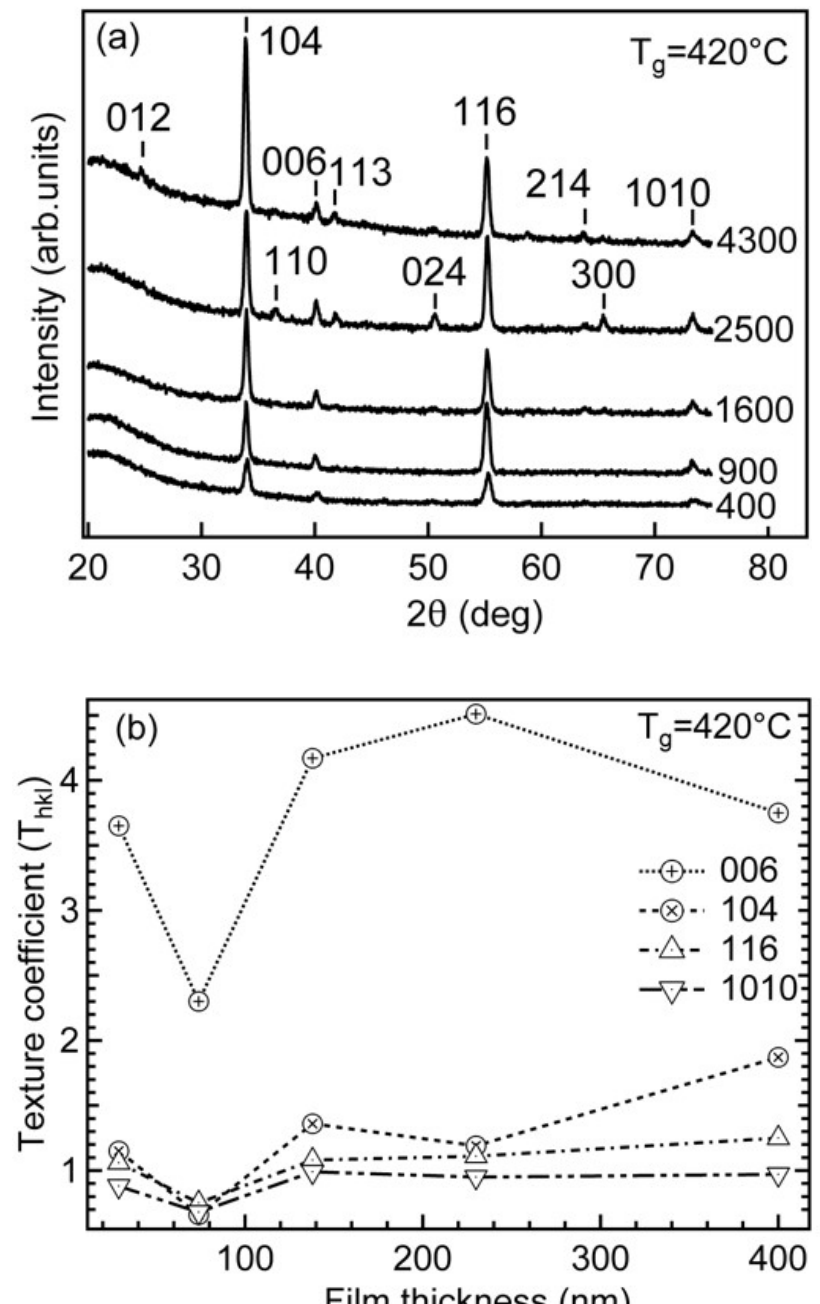

Figure 2. Diffraction patterns of chromia thin films with different cycle counts $(\mathbf{a}, \mathbf{b})$ variation of texture coefficient $\mathrm{T}_{\mathrm{hkl}}$ for the dominating reflections (104), (006), (116) and (1010) as a function of the film thickness (b) deposited at $420^{\circ} \mathrm{C}$. 
The $\theta / 2 \theta-X R D$ pattern of the film deposited with 2500 cycles showed (bottom curve in Figure 3) two strong reflections (104 and 1010) and four weak reflections (006, 113, 116, 122), whereas the IP-XRD pattern exhibited two stronger reflections from the (104) and (110) lattice planes and weaker reflections from the (113), (202), (116), (214) and (300) planes. The appearance of the $\theta / 2 \theta$-reflection from the plane (104) and IP reflection from plane (110) are a clear indication that the preferred growth of this film was in the (104) plane or in the plane where the inclination angle relative to (104) plane was small. The high value of the full width of the half maximum (FWHM) of the 1010 reflection $\left(\Delta \omega=51^{\circ}\right)$ suggests that the mosaicity of this film was very high and the preferred growth direction varied approximately from -25 to $+25^{\circ}$ relative to the surface normal of the (104) plane. The refinement of the cell parameters determined from the IP and $\theta / 2 \theta-X R D$ patterns and calculation of the lattice strain, relative to the parameters from the database (ICDD PDF-2), showed that the crystal lattice was slightly compressed $(0.05-0.1 \%)$ in the direction of the surface normal and stretched approximately parallel to the surface by the same amount.
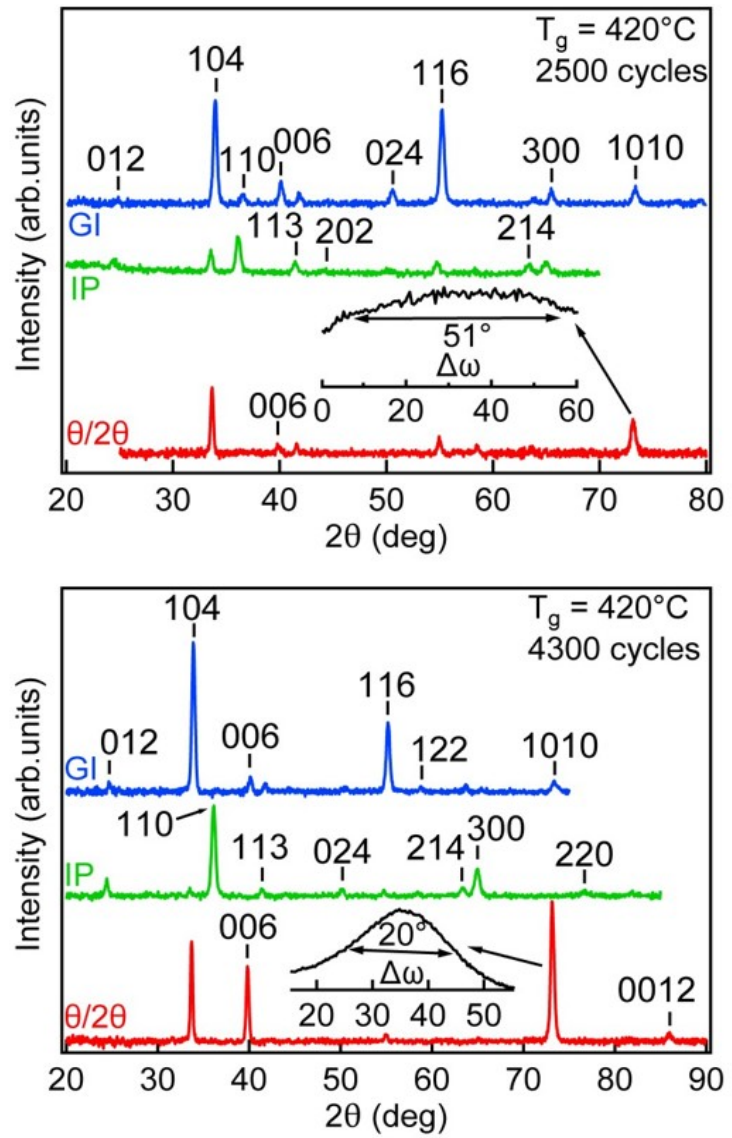

Figure 3. XRD patterns recorded in grazing incidence (GI), in-plane (IP) and symmetrical $(\Theta / 2 \Theta)$ setup for film grown at $420{ }^{\circ} \mathrm{C}$ with 2500 and 4300 cycles. The inset above the $\Theta / 2 \Theta-X R D$ pattern presents rocking curve ( $\omega$-scan) of 1010 reflection showing FWHM of approximately $51^{\circ}$ for 2500 cycles and $20^{\circ}$ for 4300 cycles.

The IP and $\theta / 2 \theta-X R D$ patterns from the film deposited with 4300 cycles showed (Figure 3) that, beside the (104) plane, the (001) plane appeared as a preferred growth plane. A relatively high intensity of the 006 reflection, the appearance of the 0012 reflection on the $\theta / 2 \theta-X R D$ pattern, the two times smaller FWHM of the rocking curve of the 1010 reflection and the approximately 2.5-3 times larger values of the lattice strain (compared to the film deposited with 2500 cycles), but also strong 110 and 300 reflections on the IP-XRD patterns of this film, allowed us to conclude that, in thicker films (above $230 \mathrm{~nm}$ ), the mosaicity decrease is accompanied by a preferred growth in the (001) plane. 
The results of the film thicknesses deposited at $420^{\circ} \mathrm{C}$ and the respective crystallite sizes are presented in Figure 4. The thickness measurement error for the thickest film was around $10 \mathrm{~nm}$ and for thinner films (below $100 \mathrm{~nm}$ ) from 1 to $3 \mathrm{~nm}$, reducing in coherence with the film thickness.

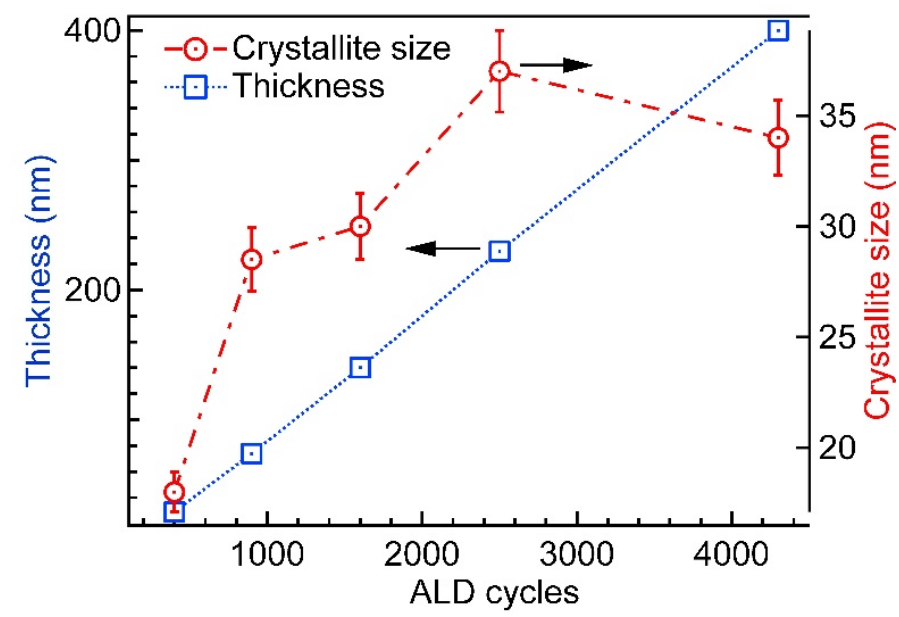

Figure 4. Variation of film thickness and $X R D$ apparent crystallite size $\left(D_{y}\right)$ with the number of deposition cycles for $\mathrm{Cr}_{2} \mathrm{O}_{3}$ samples grown at $420^{\circ} \mathrm{C}$.

The growth rate of $\mathrm{Cr}_{2} \mathrm{O}_{3}$ at $420{ }^{\circ} \mathrm{C}$, calculated from the slope of the film thickness in variation with ALD cycles, was $0.096 \mathrm{~nm} /$ cycle (determination coefficient $\mathrm{R}^{2}=0.99$ ). The linear correlation of the cycle count and resultant thin film thickness are characteristic of ALD.

It can be seen that the apparent crystallite size $\left(D_{v}\right)$ depended remarkably on the number of growth cycles or, in other words, on film thickness. The crystallites grew fast during the first 900 cycles of deposition, reaching the size of about $30 \mathrm{~nm}$. The further increase of crystallites proceeded considerably slower-within the next 1300 cycles the increase was only about $7 \mathrm{~nm}$.

The deposition temperature $\mathrm{T}_{\mathrm{g}}$ was also an important factor that controlled the crystallite size of $\mathrm{Cr}_{2} \mathrm{O}_{3}$. Figure 5 shows that $\mathrm{D}_{\mathrm{v}}$ increased fast with the increase of $\mathrm{T}_{\mathrm{g}}$ from 330 to $375^{\circ} \mathrm{C}$. Starting from $\mathrm{T}_{\mathrm{g}}=380^{\circ} \mathrm{C}$, the increase slowed down and saturated finally at $420{ }^{\circ} \mathrm{C}$, reaching the maximum value of about $27-30 \mathrm{~nm}$.

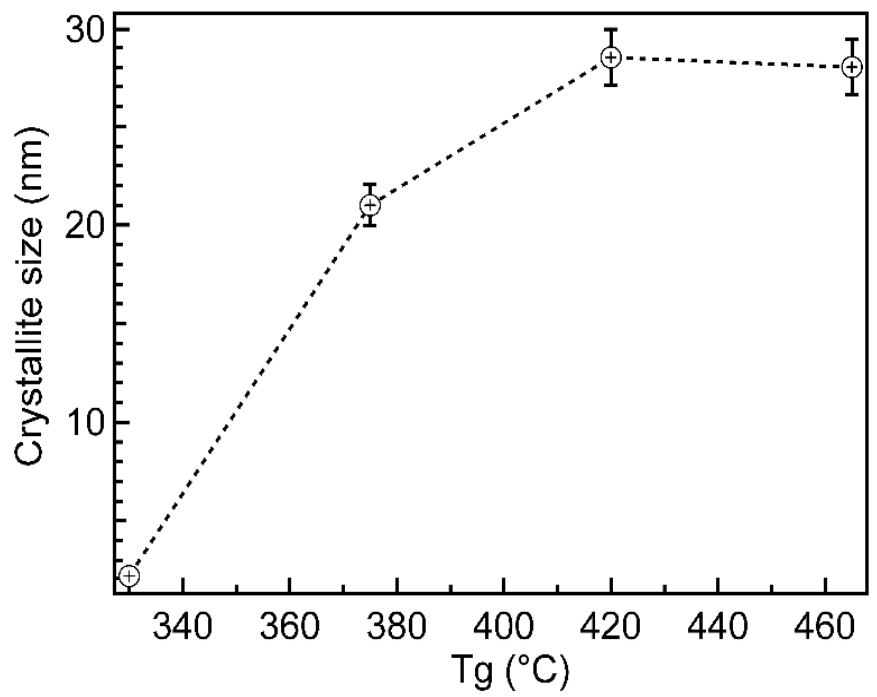

Figure 5. X-ray apparent crystallite size $\left(D_{v}\right)$ in variation of deposition temperature $\left(\mathrm{T}_{\mathrm{g}}\right)$ for $\mathrm{Cr}_{2} \mathrm{O}_{3}$ films. The thickness of the films was in the range of $68-85 \mathrm{~nm}$. 
Khojieri et al. deposited at room temperature approximately $80 \mathrm{~nm}$ thick films of $\mathrm{Cr}_{2} \mathrm{O}_{3}$ on monocrystalline silicon by using DC magnetron sputtering [29]. Annealing a sample at $400{ }^{\circ} \mathrm{C}$ resulted in grain sizes approximately $28-31 \mathrm{~nm}$, which is comparable to current work results.

The deposition conditions and the respective apparent crystallite size, film thickness and other results, determined by X-ray measurements, are gathered in Table 1 . The integral width $\beta$ of a reflection was the parameter that was used for calculation of crystallite size. Here it is presented for (104) reflection. Respective values can be seen in Table 1, which correspond to apparent X-ray crystallite size of 20-30 $\mathrm{nm}$. The unit cell parameters compare well to database values.

Table 1. Summarized results of X-ray analysis of $A L D \mathrm{Cr}_{2} \mathrm{O}_{3}$ thin films.

\begin{tabular}{ccccccc}
\hline $\begin{array}{c}\text { Cycle } \\
\text { Count }\end{array}$ & $\begin{array}{c}\text { Thickness } \\
(\mathbf{n m})\end{array}$ & $\begin{array}{c}\text { Growth } \\
\text { Tempera- } \\
\text { ture Tg } \\
\left({ }^{\circ} \mathbf{C}\right)\end{array}$ & $\begin{array}{c}\text { Crystallite } \\
\text { Size }(\mathbf{n m})\end{array}$ & $\begin{array}{c}\text { Integral } \\
\text { Width } \\
\boldsymbol{\beta}_{\mathbf{1 0 4}}\end{array}$ & $\begin{array}{c}\text { Unit Cell a } \\
\text { (nm) }\end{array}$ & $\begin{array}{c}\text { Unit Cell c } \\
(\mathbf{n m})\end{array}$ \\
\hline 4300 & 400 & 420 & 34 & $0.46(1)$ & 0.495 & 1.355 \\
2500 & 230 & 420 & 37 & $0.49(2)$ & 0.495 & 1.359 \\
1600 & 147 & 420 & 30 & $0.52(2)$ & 0.496 & 1.358 \\
900 & 74 & 420 & 28.5 & $0.53(3)$ & 0.495 & 1.359 \\
400 & 28 & 420 & 18 & $0.61(3)$ & & \\
1300 & 68 & 330 & 2.2 & & & \\
1000 & 75 & 375 & 21 & & & \\
900 & 85 & 465 & 28 & & & \\
\hline
\end{tabular}

\subsection{Nanoindentation}

\subsubsection{Relation of Hardness and Modulus to the Deposition Temperature}

The relation of the deposition temperature $T_{g}$ and the averaged reduced moduli of the films with thicknesses of $68-85 \mathrm{~nm}$ is shown in Figure 6. It can be seen that there was some dependence of moduli on $\mathrm{T}_{\mathrm{g}}$, but the difference was low-about $10 \mathrm{GPa}(\sim 10 \%)$ in between X-ray amorphous and crystalline thin films at the displacement of $20 \mathrm{~nm}$. A likely reason for such low differences was the influence of a softer $\mathrm{SiO}_{2}$ substrate. Considering that the thin films had thicknesses of only about $68-85 \mathrm{~nm}$, at the displacements of $20 \mathrm{~nm}$, the substrate reduced the measured values and the differences thereof.

The differences in the averaged hardness values were within 15\% (Figure 6). The higher values corresponded to the films with the appearance of the crystalline $\mathrm{Cr}_{2} \mathrm{O}_{3}$.

Pang et al. showed that the hardness and modulus of chromia thin film do increase with the increase in crystallinity [28]. They used reactive magnetron sputtering to produce $\mathrm{Cr}_{2} \mathrm{O}_{3}$ films and measured the range of hardness to be 11-21 GPa and 170-234 GPa for modulus, depending on the crystallinity. Khojier et al. measured the hardness of DC magnetron sputtered and annealed at $300^{\circ} \mathrm{C}$ and $400^{\circ} \mathrm{C}$ samples to be around 17-21 GPa and the respective moduli around 160-185 GPa [29].

The scattering of the nanoindentation results taken at $20 \mathrm{~nm}$ of displacement are presented in the histograms (Figure 7). It can be seen that the X-ray amorphous thin film deposited at $330{ }^{\circ} \mathrm{C}$ had lower scattering ( $\left.\pm 10 \mathrm{GPa}\right)$ than the crystalline counterpart $( \pm 35 \mathrm{GPa})$ deposited at $465^{\circ} \mathrm{C}$. As an overall notice, the scatter widened with the growth temperature $\mathrm{T}_{\mathrm{g}}$. 

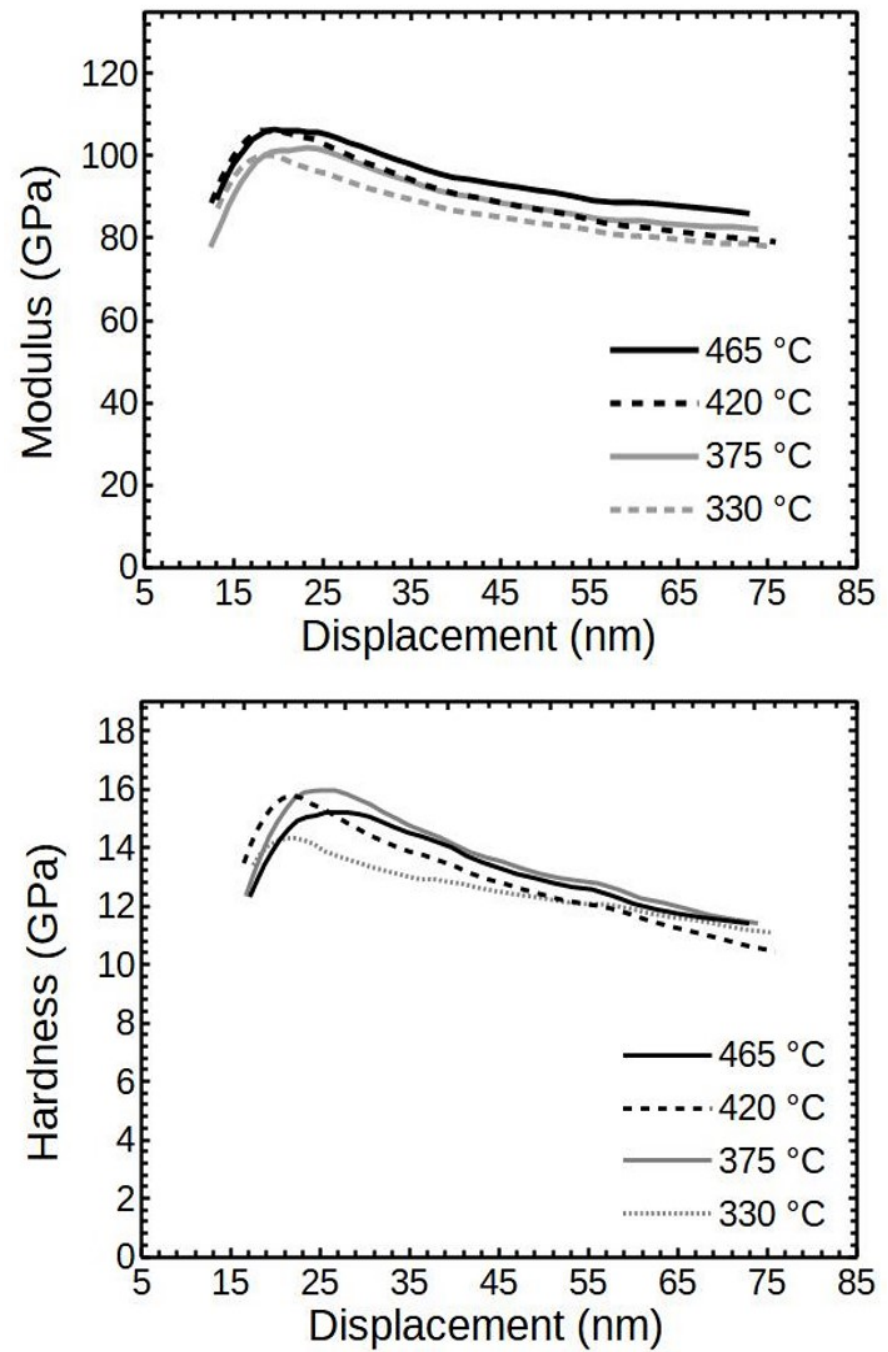

Figure 6. The averaged modulus and hardness values of $A L D \mathrm{Cr}_{2} \mathrm{O}_{3}$ deposited at different temperatures. $\mathrm{Cr}_{2} \mathrm{O}_{3}$ layer thicknesses are around $68-85 \mathrm{~nm}$.
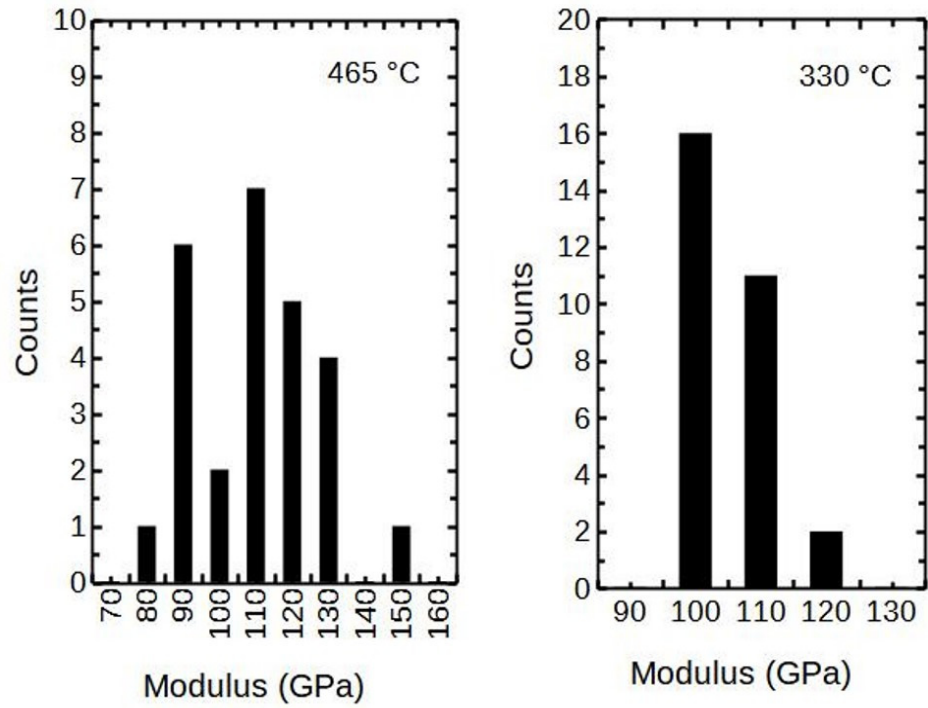

Figure 7. The scatter of modulus measurements of the 85 and $68 \mathrm{~nm}$ thick films, respectively. 


\subsubsection{Relation between Hardness, Modulus and Thickness of Chromia}

Figure 8 visualizes the relation between the modulus and the deposited thin film thickness (deposited at $420{ }^{\circ} \mathrm{C}$ ). It indicates that the softer substrate has a reducing impact on the results, which diminished inversely with film thickness. The hardness showed similar trends as the moduli (Figure 8).
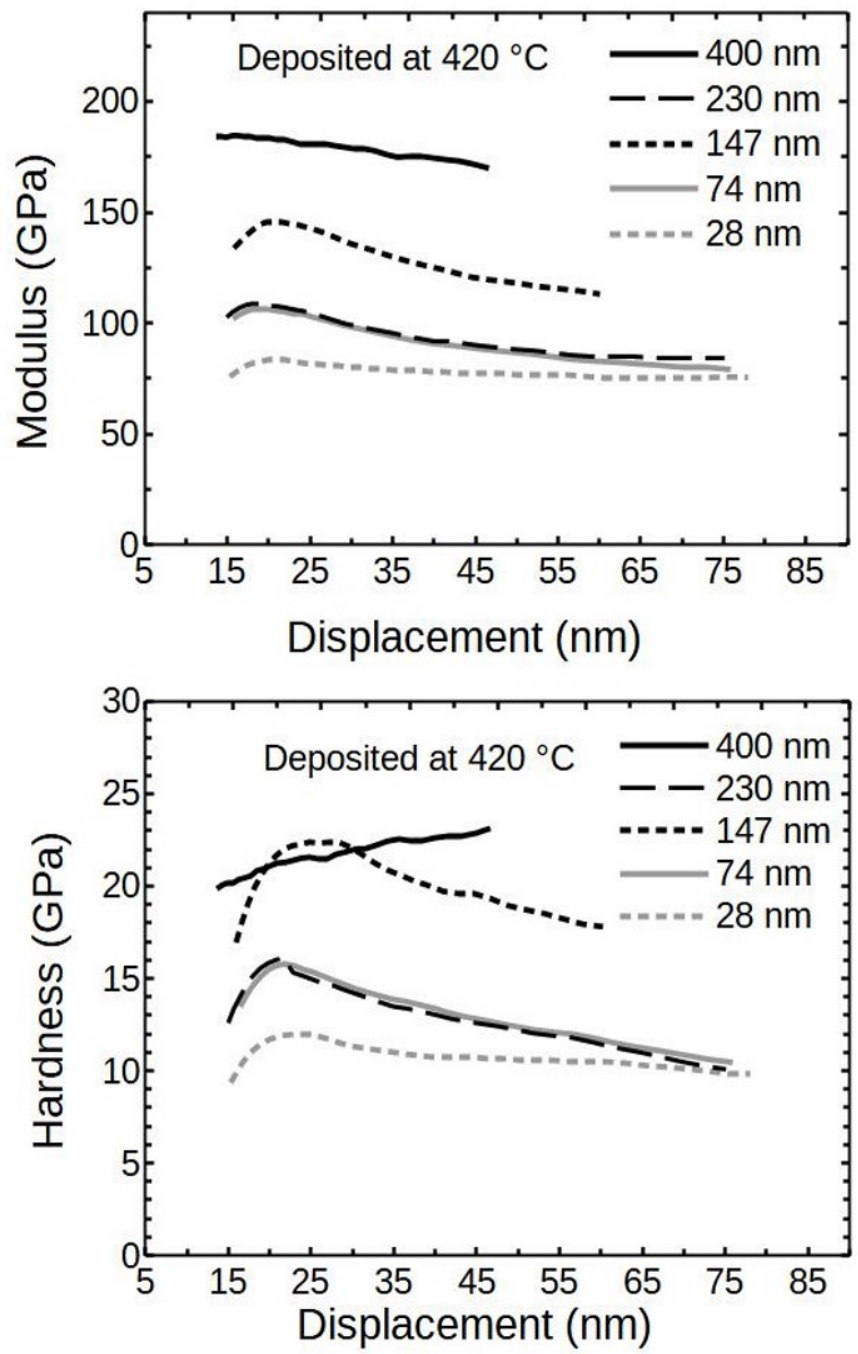

Figure 8. Modulus and hardness of $\mathrm{ALD} \mathrm{Cr}_{2} \mathrm{O}_{3}$ thin films deposited at $420{ }^{\circ} \mathrm{C}$.

It can be seen that the hardness and modulus of the $230 \mathrm{~nm}$ thick sample had considerably lower values than 147 or $400 \mathrm{~nm}$ films. A logical expectation would be for the result to be positioned in between 147 and $400 \mathrm{~nm}$ thick samples. The detrimental effect was likely caused by the increased mosaicity and the presence of differently oriented crystallites, as shown in the XRD analysis.

The reducing effect caused by the substrate was not confirmed for the $400 \mathrm{~nm}$ thick film and the hardness seemed to increase perpetually. Therefore, the sample was investigated further. The second reason for a more in-depth search was an attempt to find the properties corresponding solely to the ALD $\mathrm{Cr}_{2} \mathrm{O}_{3}$ thin film.

The triboindenter was recalibrated to a displacement upper limit of about $300 \mathrm{~nm}$ because the indentation depths were expected to exceed the $100 \mathrm{~nm}$ limit of initial calibration. The using of maximum indentation forces of 4,7 and $10 \mathrm{mN}$ revealed that the results behaved at higher displacements, as expected, clearly showing the substrate influence (Figure 9). 

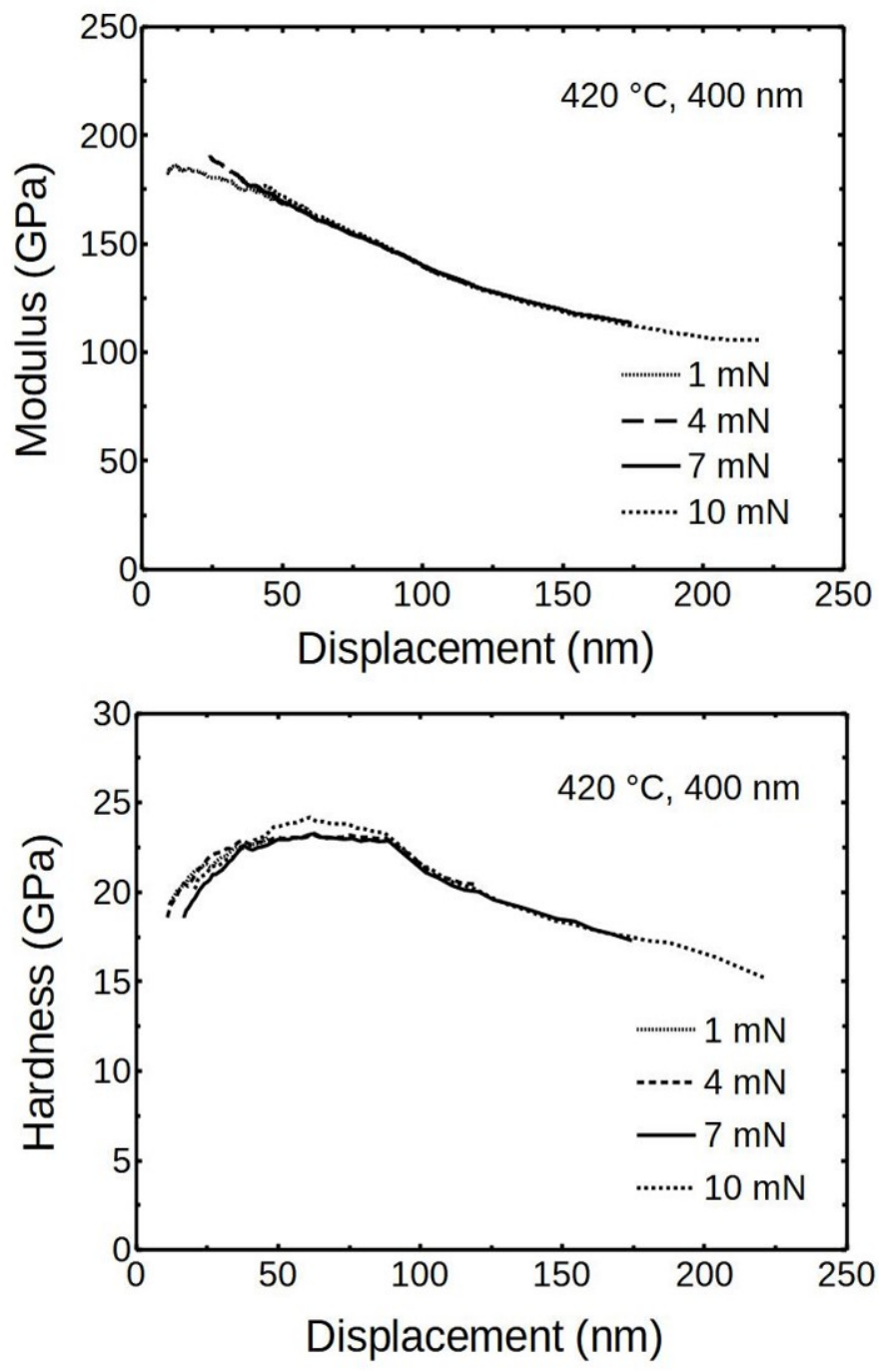

Figure 9. The averaged modulus and hardness of ALD chromia as measured by using different maximum forces.

Figure 9 indicates that the averaged measurements point at the modulus of elasticity of $\mathrm{ALD} \mathrm{Cr} \mathrm{O}_{3}$ was around $200 \pm 20 \mathrm{GPa}$. This compares well with the results published by Pang and Khojier, but it is about 80 GPa less than in Saeki's work [26,27]. Saeki et al. calculated and measured at room temperature the modulus of elasticity of $\alpha-\mathrm{Cr}_{2} \mathrm{O}_{3}$ to be $286 \mathrm{GPa}$. First-principles calculations indicated the bulk modulus of $\mathrm{Cr}_{2} \mathrm{O}_{3}$ to be around $240 \mathrm{GPa}$ at $300 \mathrm{~K}$, which is quite close to current results [43].

The averaged results for hardness at different loads gave similar curves, overlapping and showing a "plateau" at the displacement range of 30-80 $\mathrm{nm}$, where the hardness was around $22.5 \pm 1 \mathrm{GPa}$ (Figure 9). The initial increasing hardness values, seen in measurements done on $400 \mathrm{~nm}$ film by using $1 \mathrm{mN}$, can be viewed as just the lead to the plateau.

The averaged modulus of $200 \mathrm{GPa}$ and hardness of $22.5 \mathrm{GPa}$ are characteristics of the ALD $\mathrm{Cr}_{2} \mathrm{O}_{3}$ thin film deposited at given conditions. It had a remarkably high hardness compared to the values previously reported for oxide thin films deposited by ALD. In most cases, the reported values were below $15 \mathrm{GPa}$ [44-47]. Although the hardness here did not reach the super-hardness level of $40 \mathrm{GPa}$, the $22 \mathrm{GPa}$ would be a good starting point to develop super-hard ALD $\mathrm{Cr}_{2} \mathrm{O}_{3}$-based films [10].

The summarized results of XRD and nanoindentation of current work are gathered in Table 2. 
Table 2. XRD and averaged indentation hardness and modulus results given at $20 \mathrm{~nm}$ of tip displacement.

\begin{tabular}{cccccc}
\hline Cycle Count & $\begin{array}{c}\text { Thickness } \\
(\mathbf{n m})\end{array}$ & $\begin{array}{c}\text { Growth } \\
\text { Temp. } \mathbf{T}_{\mathbf{g}} \\
\left(\mathbf{~}^{\mathbf{C}} \mathbf{)}\right.\end{array}$ & $\begin{array}{c}\text { Crystallite } \\
\text { Size }(\mathbf{n m})\end{array}$ & $\begin{array}{c}\text { Hardness } \\
\mathbf{( G P a})\end{array}$ & $\begin{array}{c}\text { Modulus } \\
(\mathbf{G P a})\end{array}$ \\
\hline 4300 & 400 & 420 & 34 & 21.1 & 183 \\
2500 & 230 & 420 & 37 & 15.9 & 108 \\
1600 & 147 & 420 & 30 & 21.2 & 145 \\
900 & 74 & 420 & 28.5 & 15.5 & 106 \\
400 & 28 & 420 & 18 & 11.7 & 83 \\
1300 & 68 & 330 & 2.2 & 12.5 & 105 \\
1000 & 75 & 375 & 21 & 14.9 & 99 \\
900 & 85 & 465 & 29 & 14.3 & 106 \\
\hline
\end{tabular}

It is clear from Table 2 that the sample with 2500 deposition cycles had markedly lower hardness and modulus compared to samples with 1600 and 4300 cycles. This could be attributed to the different crystallite orientations, as was seen from XRD (Figure 2). Crystallite orientation is known to have influence on material properties [12,48]. On the other hand, the determined XRD apparent crystallite sizes did not correlate well with respective hardnesses or moduli. The hardness value for $230 \mathrm{~nm}$ thick film was considerably lower than for neighboring samples, even though the crystallites had fairly similar sizes. The lower hardness could not be attributed to intrinsic stresses as the unit cell parameters in Table 1 did not indicate any remarkable stresses.

The $\mathrm{Cr}_{2} \mathrm{O}_{3}$ film deposited at $420{ }^{\circ} \mathrm{C}$ with 4300 ALD cycles was also studied using scanning transmission electron microscopy. Figure 10a shows a cross-sectional bright-field STEM image of the $\mathrm{Cr}_{2} \mathrm{O}_{3}$ film on $\mathrm{SiO}_{2}$ substrate with a platinum protection layer on top. Due to the lower atomic number, the $\mathrm{SiO}_{2}$ substrate appears significantly brighter compared to the $\mathrm{Cr}_{2} \mathrm{O}_{3}$ film on the image. The image shows continuous dense $\mathrm{Cr}_{2} \mathrm{O}_{3}$ with no gaps or voids between various nucleated grains, which indicates a complete coalescence of the nucleation islands. The thickness of the film is relatively uniform, but some surface roughness is present. The source of the surface roughness might be a result of the formation of quite large crystallites. The thickness of the film measured on the STEM image is around $400 \mathrm{~nm}$, which is in agreement with the values obtained by the XRR studies.
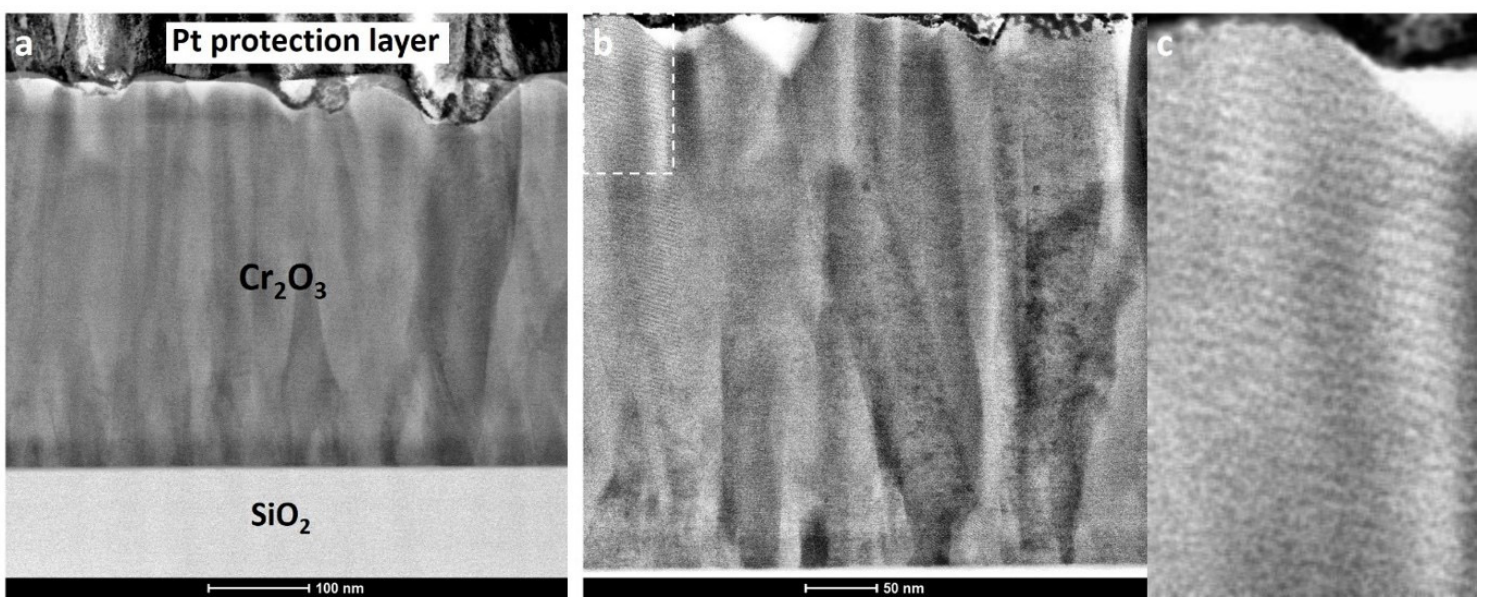

Figure 10. Bright-field STEM images of $\mathrm{Cr}_{2} \mathrm{O}_{3}$ film on $\mathrm{SiO}_{2}$ glass substrate deposited at $420{ }^{\circ} \mathrm{C}$ with 4300 ALD cycles. The scales are $100 \mathrm{~nm}$ and $50 \mathrm{~nm}$ for the $(\mathbf{a}, \mathbf{b})$ image, respectively. (c) is an enlarged cut-out of top left corner of the image $(\mathbf{b})$.

As can be seen by the more uniform contrast, as well as the large areas with uniform Moire fringes (Figure 10b,c) closer to the surface of the film, the size of the grains perpendicular to the substrate tended to increase with film thickness. The increase in the lateral 
size of the favorably oriented grains led to the impairment of the growth of other grains and a decrease of mosaicity of the film.

Similar columnar structures were reported previously in the case of magnetron sputtered $\mathrm{Cr}_{2} \mathrm{O}_{3}$, but the authors did not discuss the relationship between mechanical properties and crystallite size, film thickness or the columnar microstructure [10,24]. It seems that, at the half height in the STEM image, there is a change in crystallite nucleation site count and the crystallites seem to start coalescing. This kind of growth kinetics change can introduce local mechanical stresses which, again, could initiate phase changes in a material to relieve the stress. Considering that the alpha form of $\mathrm{Cr}_{2} \mathrm{O}_{3}$ is a stable polymorph, the possible phase change is unlikely. On the other hand, it cannot be ruled out that residual stress somewhat changes the crystallite orientations or positioning and this could occur ex situ, over a period of time. An additional 70\% thickness increase (from $230 \mathrm{~nm}$ to $400 \mathrm{~nm}$ ) could, again, stabilize the structure enough that any probable changes, such as increased mosaicity, are hindered. This could be the reason why the XRD results and mechanical properties are different for $\mathrm{Cr}_{2} \mathrm{O}_{3}$ thin films with thicknesses of 230 and $400 \mathrm{~nm}$. Unfortunately, the current set-up was to characterize the thin films ex situ and not in situ. The latter could be considered for next experiments to get more insight. Abadis et al. published a comprehensive review on stresses in thin films and related effects, including phase changes, detrimental effect on mechanical properties and so on [49].

\section{Conclusions}

The study suggests that $\mathrm{ALD} \mathrm{Cr}_{2} \mathrm{O}_{3}$ is hard and relatively stiff but, in some cases, the uniform mechanical behavior might be hard to achieve. It can be concluded that the X-ray amorphous ALD $\mathrm{Cr}_{2} \mathrm{O}_{3}$ had the lowest dispersion of hardness and modulus, but the averaged values remained lower as compared to crystalline samples. Higher crystallinity in thin films results in higher hardness and modulus but also the higher scatter of the results, which has to be considered in applications. The optimization of deposition conditions could help to gain an ALD $\mathrm{Cr}_{2} \mathrm{O}_{3}$ thin film with a lower dispersion of properties.

The research showed correlation between ALD conditions, such as growth temperature, and resulting mechanical properties, such as hardness, which can be taken as a guide in application or further research. The measurements showed that the averaged hardness was $22.5 \pm 1 \mathrm{GPa}$ and the modulus was $200 \pm 25 \mathrm{GPa}$ for the film deposited at $420^{\circ} \mathrm{C}$. The hardness of thin films indicates that it could be used as starting point for developing super-hard ALD coatings.

Atomic-layer-deposited $\mathrm{Cr}_{2} \mathrm{O}_{3}$ looks like a very good candidate material as a mechanically protective coating. The $\mathrm{Cr}_{2} \mathrm{O}_{3}$ coating would considerably enhance the surface properties of, for instance, the silicon- or silicon-oxide-based parts of micromechanical devices. Due to the conformal growth of ALD thin films, these could be applied on basically arbitrary shapes, which is very convenient in the case of micro-electromechanical systems. The actual performance, naturally, depends on the selected substrate, thin film thickness and deposition conditions (i.e., the temperature).

Author Contributions: Conceptualization, data curation, project administration, T.J.; formal analysis, T.J. and H.M.; investigation, T.J. and A.T. (Aivar Tarre); writing original draft, T.J., H.M. and J.K.; writing-review and editing, A.T. (Aivar Tarre) and A.T. (Aile Tamm); funding acquisition and resources, A.T. (Aile Tamm). All authors have read and agreed to the published version of the manuscript.

Funding: This work was funded by the European Regional Development Fund project TK134 “Emerging orders in quantum and nanomaterials", Estonian Research Agency project PRG4 "Emerging novel phases in strongly frustrated quantum magnets" and Estonian Research Agency project PRG753.

Institutional Review Board Statement: Not applicable.

Informed Consent Statement: Not applicable. 
Data Availability Statement: The data presented in this study are available on request from the corresponding author.

Acknowledgments: This work was supported by the ERDF project Centre of Technologies and Investigations of Nanomaterials (NAMUR+, project number 2014-2020.4.01.16-0123).

Conflicts of Interest: The authors declare no conflict of interest.

\section{References}

1. Tang, J.-F.; Huang, C.-H.; Lin, C.-Y.; Tsai, Y.-J.; Chang, C.-L. Effect of plasma nitriding and modulation structure on the adhesion and corrosion resistance of $\mathrm{CrN} / \mathrm{Cr}_{2} \mathrm{O}_{3}$ coatings. Surf. Coat. Technol. 2019, 379, 125051. [CrossRef]

2. Babu, P.S.; Sen, D.; Jyothirmayi, A.; Krishna, L.R.; Rao, D.S. Influence of microstructure on the wear and corrosion behavior of detonation sprayed $\mathrm{Cr}_{2} \mathrm{O}_{3}-\mathrm{Al}_{2} \mathrm{O}_{3}$ and plasma sprayed $\mathrm{Cr}_{2} \mathrm{O}_{3}$ coatings. Ceram. Int. 2018, 44, 2351-2357. [CrossRef]

3. Yıldız, B.K.; Tür, Y.K. An investigation of equibiaxial flexural strength and hardness properties of $\mathrm{Al}_{2} \mathrm{O}_{3}-\mathrm{Ni}$ nanocomposites-based microstructures with $\mathrm{ZrO}_{2}$ and $\mathrm{Cr}_{2} \mathrm{O}_{3}$ additives. Mat. Sci. Eng. A 2019, 758, 103-111. [CrossRef]

4. Yıldız, B.K.; Yılmaz, H.; Tür, Y.K. Evaluation of mechanical properties of $\mathrm{Al}_{2} \mathrm{O}_{3}-\mathrm{Cr}_{2} \mathrm{O}_{3}$ ceramic system prepared in different $\mathrm{Cr}_{2} \mathrm{O}_{3}$ ratios for ceramic armour components. Ceram. Int. 2019, 45, 20575-20582. [CrossRef]

5. Norfauzi, T.; Hadzley, A.B.; Azlan, U.A.A.; Afuza, A.A.; Faiz, M.M.; Naim, M.F. Fabrication and machining performance of ceramic cutting tool based on the $\mathrm{Al}_{2} \mathrm{O}_{3}-\mathrm{ZrO}_{2}-\mathrm{Cr}_{2} \mathrm{O}_{3}$ compositions. J. Mater. Res. Technol. 2019, 8, 5114-5123. [CrossRef]

6. He, X.; Li, C.; Liu, J.; Huang, Q.; Shen, X.; Liu, T.; Lu, A. Glass forming ability, structure and properties of $\mathrm{Cr}_{2} \mathrm{O}_{3}-\mathrm{Fe}_{2} \mathrm{O}_{3} \mathrm{Co}-\mathrm{doped}$ $\mathrm{MgO}-\mathrm{Al}_{2} \mathrm{O}_{3}-\mathrm{SiO}_{2}-\mathrm{B}_{2} \mathrm{O}_{3}$ glasses and glass-ceramics. J. Non-Cryst. Solids 2020, 529, 119779. [CrossRef]

7. Manshor, H.; Abdullah, E.C.; Azhar, A.Z.A.; Sing, Y.W.; Ahmad, Z.A. Microwave sintering of zirconia-toughened alumina (ZTA) $-\mathrm{TiO}_{2}-\mathrm{Cr}_{2} \mathrm{O}_{3}$ ceramic composite: The effects on microstructure and properties. J. Alloys Compd. 2017, 722, 458-466. [CrossRef]

8. Khodaei, M.; Yaghobizadeh, O.; Baharvandi, H.R.; Esmaeeli, S.; Javi, H. The effect of $\mathrm{Cr}_{2} \mathrm{O}_{3}$ additions on sinterability and mechanical properties of liquid-phase sintered SiC ceramics. J. Alloys Compd. 2020, 829, 154501. [CrossRef]

9. Xia, J.F.; Nian, H.Q.; Liu, W.; Wang, X.G.; Jiang, D.Y. Effect of $\mathrm{Cr}_{2} \mathrm{O}_{3}$ derived from $\mathrm{Cr}\left(\mathrm{NO}_{3}\right)_{3} \cdot 9 \mathrm{H}_{2} \mathrm{O}$ precursor on the densification and mechanical properties of zirconia-toughened alumina (ZTA) composites. Ceram. Int. 2016, 42, 9116-9124. [CrossRef]

10. Mohammadtaheri, M.; Li, Y.; Corona-Gomez, J.; Yang, Q. An investigation on synthesis and characterization of superhard Cr-Zr-O coatings. Surf. Coat. Technol. 2019, 375, 694-700. [CrossRef]

11. Yang, X.; Dong, S.; Zeng, J.; Zhou, X.; Jiang, J.; Deng, L.; Cao, X. Sliding wear characteristics of plasma-sprayed $\mathrm{Cr}_{2} \mathrm{O}_{3} \mathrm{Coatings}$ with incorporation of metals and ceramics. Ceram. Int. 2019, 45, 20243-20250. [CrossRef]

12. Pedersen, K.; Bøttiger, J.; Sridharan, M.; Sillassen, M.; Eklund, P. Texture and microstructure of $\mathrm{Cr}_{2} \mathrm{O}_{3}$ and $(\mathrm{Cr}, \mathrm{Al})_{2} \mathrm{O}_{3}$ thin films deposited by reactive inductively coupled plasma magnetron sputtering. Thin Solid Film. 2010, 518, 4294-4298. [CrossRef]

13. Carta, G.; Natali, M.; Rossetto, G.; Zanella, P.; Salmaso, G.; Restello, S.; Rigato, V.; Kaciulis, S.; Mezzi, A. A Comparative Study of $\mathrm{Cr}_{2} \mathrm{O}_{3}$ Thin Films Obtained by MOCVD using Three Different Precursors. Chem. Vap. Depos. 2005, 11, 375-380. [CrossRef]

14. Kao, A.S.; Doerner, M.F.; Novotny, V.J. Processing effects on the tribological characteristics of reactively sputtered chromium oxide $\left(\mathrm{Cr}_{2} \mathrm{O}_{3}\right)$ overcoat films. J. Appl. Phys. 1989, 66, 5315-5321. [CrossRef]

15. Luo, F.; Pang, X.; Gao, K.; Yang, H.; Wang, Y. Role of deposition parameters on microstructure and mechanical properties of chromium oxide coatings. Surf. Coat. Technol. 2007, 202, 58-62. [CrossRef]

16. Singh, J.; Verma, V.; Kumar, R. Preparation and structural, optical studies of Al substituted chromium oxide $\left(\mathrm{Cr}_{2} \mathrm{O}_{3}\right)$ nanoparticles. Vacuum 2019, 159, 282-286. [CrossRef]

17. Yang, S.; Liu, S.; Lan, C.; Yang, S. Single crystalline $\mathrm{Cr}_{2} \mathrm{O}_{3}$ nanowires/nanobelts: $\mathrm{CrCl}_{3}$ assistant synthesis and novel magnetic properties. Appl. Surf. Sci. 2012, 258, 8965-8969. [CrossRef]

18. Baraskar, P.; Chouhan, R.; Agrawal, A.; Choudhary, R.J.; Sen, P. Weak ferromagnetism at room temperature in Ti incorporated $\mathrm{Cr}_{2} \mathrm{O}_{3}$ thin film. Phys. B Condens. Matter 2019, 571, 36-40. [CrossRef]

19. Nadeem, K.; Kamran, M.; Javed, A.; Zeb, F.; Hussain, S.S.; Mumtaz, M.; Krenn, H.; Szabo, D.V.; Brossmann, U.; Mu, X. Role of surface spins on magnetization of $\mathrm{Cr}_{2} \mathrm{O}_{3}$ coated $\gamma-\mathrm{Fe}_{2} \mathrm{O}_{3}$ nanoparticles. Solid State Sci. 2018, 83, 43-48. [CrossRef]

20. Yang, T.H.; Mal, S.; Jin, C.; Narayan, R.J.; Narayan, J. Epitaxial $\mathrm{VO}_{2} / \mathrm{Cr}_{2} \mathrm{O}_{3}$ / sapphire heterostructure for multifunctional applications. Appl. Phys. Lett. 2011, 98, 022105201. [CrossRef]

21. $\mathrm{Mu}, \mathrm{S}$.; Belashchenko, K.D. Influence of strain and chemical substitution on the magnetic anisotropy of antiferromagnetic $\mathrm{Cr}_{2} \mathrm{O}_{3}$ : An ab-initio study. Phys. Rev. Mater. 2019, 3, 034405. [CrossRef]

22. Asghari, S.; Haghighi, M.; Taghavinezhad, P. Plasma-enhanced scattering of $\mathrm{Cr}_{2} \mathrm{O}_{3}$ over ceria-doped MCM-41 nanostructured catalyst used in $\mathrm{CO}_{2}$ oxidative dehydrogenation of ethane to ethylene. Microporous Mesoporous Mater. 2019, 279, 165-177. [CrossRef]

23. Kim, T.H.; Yoon, J.W.; Kang, Y.C.; Abdel-Hady, F.; Wazzan, A.A.; Lee, J.H. A strategy for ultrasensitive and selective detection of methylamine using p-type $\mathrm{Cr}_{2} \mathrm{O}_{3}$ : Morphological design of sensing materials, control of charge carrier concentrations, and configurational tuning of Au catalysts. Sens. Actuators B Chem. 2017, 240, 1049-1057. [CrossRef]

24. Mohammadtaheri, M.; Yang, Q.; Li, Y.; Corona-Gomez, J. The Effect of Deposition Parameters on the Mechanical Properties of Chromium Oxide Coatings Deposited by Reactive Magnetron Sputtering. Coatings 2018, 8, 111. [CrossRef] 
25. Hafeez, M.; Saleemi, A.S.; Rehman, S.U.; Adrees, M.; Mehmood, S.; Mir, I.A.; Zhu, L. CVD growth of layered $\mathrm{Cr}_{2} \mathrm{O}_{3}$ hexagonal flakes for optoelectronic applications. Appl. Surf. Sci. 2021, 536, 147713. [CrossRef]

26. Tarre, A.; Aarik, J.; Mändar, H.; Niilisk, A.; Pärna, R.; Rammula, R.; Uustare, T.; Rosental, A.; Sammelselg, V. Atomic layer deposition of $\mathrm{Cr}_{2} \mathrm{O}_{3}$ thin films: Effect of crystallization on growth and properties. Appl. Surf. Sci. 2008, 254, 5149-5156. [CrossRef]

27. Sammelselg, V.; Tarre, A.; Lu, J.; Aarik, J.; Niilisk, A.; Uustare, T.; Netšipailo, I.; Rammula, R.; Pärna, R.; Rosental, A. Structural characterization of $\mathrm{TiO}_{2}-\mathrm{Cr}_{2} \mathrm{O}_{3}$ nanolaminates grown by atomic layer deposition. Surf. Coat. Technol. 2010, 204, 2015-2018. [CrossRef]

28. Tripathi, T.S.; Niemelä, J.P.; Karppinen, M. Atomic layer deposition of transparent semiconducting oxide $\mathrm{CuCrO}_{2}$ thin films. $J$. Mater. Chem. C 2015, 3, 8364-8371. [CrossRef]

29. Sousa, P.M.; Silvestre, A.J.; Conde, O. $\mathrm{Cr}_{2} \mathrm{O}_{2}$ thin films grown at room temperature by low pressure laser chemical vapour deposition. Thin Solid Film. 2011, 519, 3653-3657. [CrossRef]

30. Pang, X.; Gao, K.; Volinsky, A.A. Microstructure and mechanical properties of chromium oxide coatings. J. Mater. Res. 2007, 22, 3531-3537. [CrossRef]

31. Khojier, K.; Savaloni, H.; Ashkabusi, Z.; Dehnavi, N.Z. Structural, mechanical and tribological characterization of chromium oxide thin films prepared by post-annealing of Cr thin films. Appl. Surf. Sci. 2013, 284, 489-496. [CrossRef]

32. Saeki, I.; Ohno, T.; Seto, D.; Sakai, O.; Sugiyama, Y.; Sato, T.; Yamauchi, A.; Kurokawa, K.; Takeda, M.; Onishi, T. Measurement of Young's modulus of oxides at high temperature related to the oxidation study. Mater. High Temp. 2014, 28, 264-268. [CrossRef]

33. Miikkulainen, V.; Leskelä, M.; Ritala, M.; Puurunen, R.L. Crystallinity of inorganic films grown by atomic layer deposition: Overview and general trends. J. Appl. Phys. 2013, 113, 021301. [CrossRef]

34. Węgrzyniak, A.; Jarczewski, S.; Wach, A.; Hędrzak, E.; Kuśtrowski, P.; Michorczyk, P. Catalytic behaviour of chromium oxide supported on CMK-3 carbon replica in the dehydrogenation propane to propene. Appl. Catal. A Gen. 2015, 508, 1-9. [CrossRef]

35. Brytavskyi, I.; Hušeková, K.; Myndrul, V.; Pavlenko, M.; Coy, E.; Zaleski, K.; Gregušová, D.; Yate, L.; Smyntyna, V.; Iatsunskyi, I. Effect of porous silicon substrate on structural, mechanical and optical properties of MOCVD and ALD ruthenium oxide nanolayers. Appl. Surf. Sci. 2019, 471, 686-693. [CrossRef]

36. Jõgiaas, T.; Arroval, T.; Kollo, L.; Kozlova, J.; Käämbre, T.; Mändar, H.; Tamm, A.; Hussainova, I.; Kukli, K. Atomic layer deposition of alumina on gamma- $\mathrm{Al}_{2} \mathrm{O}_{3}$ nanofibres. Phys. Status Solidi 2014, 211, 403-408. [CrossRef]

37. Jõgiaas, T.; Kollo, L.; Kozlova, J.; Tamm, A.; Hussainova, I.; Kukli, K. Effect of atomic layer deposited aluminium oxide on mechanical properties of porous silicon carbide. Ceram. Int. 2015, 41, 7519-7528. [CrossRef]

38. Tripp, M.K.; Stampfer, C.; Miller, D.C.; Helbling, T.; Herrmann, C.F.; Hierold, C.; Gall, K.; George, S.M.; Bright, V.M. The mechanical properties of atomic layer deposited alumina for use in micro- and nano-electromechanical systems. Sens. Actuators $A$ Phys. 2006, 130-131, 419-429. [CrossRef]

39. Niilisk, A.; Rosental, A.; Gerst, A.; Sammelselg, V.; Uustare, T. Atomic-scale optical monitoring of initial growth of TiO 2 thin films. In Smart Optical Inorganic Structures and Devices; International Society for Optics and Photonics: Bellingham, WA, USA, 2001; Volume 4318. [CrossRef]

40. Mändar, H.; Felsche, J.; Mikli, V.; Vajakas, T. AXES1.9: New tools for estimation of crystallite size and shape by Williamson-Hall analysis. J. Appl. Cryst. 1999, 32, 345-350. [CrossRef]

41. Barrett, C.S.; Massalski, T.B. Structure of Metals. In Crystallographic Methods, Principles and Data (International Series on Materials Science and Technology), 3rd ed.; Pergamon Press: Oxford, UK, 1980; p. 204. ISBN 978-0080261720.

42. Guo, T.; Chen, Y.; Cao, R.; Pang, X.; He, J.; Qiao, L. Cleavage cracking of ductile-metal substrates induced by brittle coating fracture. Acta Mater. 2018, 152, 77-85. [CrossRef]

43. Wang, Y.; Fang, H.; Zacherl, C.L.; Mei, Z.; Shang, S.; Chen, L.Q.; Jablonski, P.D.; Liu, Z.K. First-principles lattice dynamics, thermodynamics, and elasticity of $\mathrm{Cr}_{2} \mathrm{O}_{3}$. Surf. Sci. 2012, 606, 1422-1425. [CrossRef]

44. Jõgiaas, T.; Zabels, R.; Tamm, A.; Merisalu, M.; Hussainova, I.; Heikkilä, M.; Maendar, H.; Kukli, K.; Ritala, M.; Leskelä, M Mechanical properties of aluminum, zirconium, hafnium and tantalum oxides and their nanolaminates grown by atomic layer deposition. Surf. Coat. Technol. 2015, 282, 36-42. [CrossRef]

45. Jõgiaas, T.; Zabels, R.; Tarre, A.; Tamm, A. Hardness and modulus of elasticity of atomic layer deposited $\mathrm{Al}_{2} \mathrm{O}_{3}-\mathrm{ZrO}_{2}$ nanolaminates and mixtures. Mater. Chem. Phys. 2020, 240, 122270. [CrossRef]

46. Berdova, M.; Liu, X.; Wiemer, C.; Lamperti, A.; Tallarida, G.; Cianci, E.; Fanciulli, M.; Franssila, S. Hardness, elastic modulus, and wear resistance of hafnium oxide-based films grown by atomic layer deposition. J. Vac. Sci. Technol. A Vac. Surf. Film. 2016, 34, 051510. [CrossRef]

47. Ylivaara, O.M.; Kilpi, L.; Liu, X.; Sintonen, S.; Ali, S.; Laitinen, M.; Julin, J.; Haimi, E.; Sajavaara, T.; Lipsanen, H.; et al. Aluminium oxide/titanium dioxide nanolaminates grown byatomic layer deposition: Growth and mechanical properties. J. Vac. Sci. Technol. A Vac. Surf. Film. 2017, 35, 01B105. [CrossRef]

48. Chen, Y.; Guo, T.; Wang, J.; Pang, X.; Qiao, L. Effects of orientation on microstructure and mechanical properties of TiN/AlN superlattice films. Scr. Mater. 2021, 201, 113951. [CrossRef]

49. Abadias, G.; Chason, E.; Keckes, J.; Sebastiani, M.; Thompson, G.B.; Barthel, E.; Doll, G.L.; Murray, C.E.; Stoessel, C.H.; Martinu, L. Review Article: Stress in thin films and coatings: Current status, challenges, and prospects. J. Vac. Sci. Technol. A Vac. Surf. Film. 2018, 36, 020801. [CrossRef] 